\title{
TİCARİ KEFİRLERİN BAZI KALİTE PARAMETRELERİNİN BELİRLENMESİ
}

\author{
Fatma Nur Ünal ${ }^{1}$, Alperen Kalyas ${ }^{1}$, Zeynep Gürbüz-Kaçan ${ }^{2}$, \\ Mustafa Şengüi ${ }^{2}$, Bayram Ürkek ${ }^{3 *}$ \\ ${ }^{1}$ Gümüşhane Üniversitesi, Fen Bilimleri Enstitüsü, Gida Mühendisliği ABD, Gümüşhane, Türkiye \\ ${ }^{2}$ Atatürk Üniversitesi, Ziraat Fakültesi, Gıda Mühendisliği Bölümü, Erzurum, Türkiye \\ ${ }^{3}$ Gümüşhane Üniversitesi, Şiran Mustafa Beyaz Meslek Yüksekokulu, Gıda İşleme Bölümü, Gümüşhane, Türkiye
}

Geliş / Received: 08.02.2020; Kabul / Accepted: 22.05.2020; Online bask1 / Published online: 03.06.2020

Ünal, F.N., Kalyas, A., Gürbüz Kaçan, Z., Şengül, M., Ürkek, B. (2020). Ticari kefirlerin bazı kalite parametrelerinin belirlenmesi. GID A (2020) 45(3) 555-563 doi: 10.15237/gida.GD20026

Ünal, F.N., Kalyas, A., Gürbüz, Kaşan, Z., Sengül, M., Ürkek, B. (2020). Ticari kefirlerin baž kalite parametrelerinin belirlenmesi. GIDA (2020) 45(3) 555-563 doi: 10.15237/gida.GD20026

\section{ÖZ}

Bu çalışmada, piyasada satışa sunulan 6 adet farklı ticari kefir örneği incelenmiştir. Kefir örneklerinin bazı fizikokimyasal (\% kurumadde, \% yağ, $\mathrm{pH}, \%$ asitlik, \% su bağlama kapasitesi), reolojik (viskozite, kıvam katsayıs1, akış davranış indeksi), mikrobiyolojik (laktobasil, laktokok, maya-küf ve koliform bakteri sayıları) ve duyusal özellikleri araştırılmışır. K4 kodlu örnek en yüksek viskozite (50 rpm'de $461.90 \mathrm{cP}$ ) ve kıvam katsayısı (K 8.16) değerlerine sahip olduğu ortaya konulmuştur. Diğer taraftan, K5 kodlu örneğin su tutma kapasitesi (\%38.75) ve viskozite (100 rpm'de $285.87 \mathrm{cP}$ ) değerleri en yüksek değerlere sahip olduğu tespit edilmiştir. Kefir örneklerinin ortalama laktobasil, laktokok ve maya-küf saylları sirasiyla 8.15-9.09, 8.39-9.34 ve 4.38-5.37 log kob/mL arasinda değiştiği belirlenmiştir. 6 örneğin hiçbirinde koliform bakteri tespit edilememiştir. Duyusal değerlendirme sonucunda tüm kefir örnekleri değerlendirilen duyusal karakteristikler açısından panelistler tarafindan düşük puanlar almıştır.

Anahtar kelimeler: Kefir, fizikokimyasal özellikler, mikrobiyolojik özellikler, reolojik özellikler

\section{DETERMINATION OF SOME QUALITY PARAMETERS OF COMMERICAL KEFIRS}

\begin{abstract}
In this study, six different commerical kefir samples obtained from markets were examined. Some physicochemical (\% dry matter, $\%$ fat, $\mathrm{pH}, \%$ acidity, $\%$ water holding capacity), rheological (viscosity, consistency coefficient, flow behavior index), microbiological (lactobacilli, lactococci, yeast and mould and coliform bacteria counts) and sensory properties of the kefir samples were investigated. The sample coded as $\mathrm{K} 4$ had the highest viscosity $(461.90 \mathrm{cP}$ at $50 \mathrm{rpm})$ and consistency coefficient value $(K 8.16)$. Water holding capacity (\%38.75) and viscosity $(285.87 \mathrm{cP}$ at $100 \mathrm{rpm})$ values of sample K5 were the highest. The average lactobacilli, lactococci and yeast and mould counts of kefir samples were between 8.159.09, 8.39-9.34 and 4.38-5.37 $\log \mathrm{CFU} / \mathrm{mL}$, respectively. Coliform bacteria were not detected in the samples. As a result of sensorial evaluation, all samples were scored low in terms of sensorial properties. Keywords: Kefir, physicochemical properties, microbiological properties, rheological properties,
\end{abstract}

\footnotetext{
* Yazışmalardan sorumlu yazar /Corresponding author

$\square$ bayramurkek@gumushane.edu.tr O (+90) 456233 1000-3600 圆 (+90) 4562331009
}

Fatma Nur Ünal; ORCID no: 0000-0002-0804-9453

Alperen Kalyas; ORCID no: 0000-0002-7483-0029

Zeynep Gürbüz-Kaçan; ORCID no: 0000-0003-4066-0241

Mustafa Şengül ; ORCID no: 0000-0001-8447-2256

Bayram Ürkek; ORCID no: 0000-0002-7909-7364 


\section{GİRIŞ}

Viskoz, ferahlatıcı, çok az miktarda alkol ve karbondioksit içeren kefir geleneksel fermente bir süt içeceğidir (Farnworth, 2005). Kefir, yoğurt ve kımı gibi fermente süt ürünlerinin besleyici ve terapötik özellikleri bu ürünlere olan ilgiyi arttırmaktadır (Yıldız-Akgül vd., 2018).

Kefirin anlamı "güzel hissettiren" anlamındaki Türkçe "keyif" kelimesinden türemiştir (YıldızAkgül vd., 2018). Kefir "kefer", "kippi", "kanphon", "kiaphur" gibi farklı isimlerle de anılmaktadır (Ürkek vd., 2011; Sulmiyati vd., 2019). Kefir içerdiği birçok farklı starter kültür içeriği ile diğer fermente süt ürünlerinden ayrilmaktadır (Ylldız-Akgül vd., 2018). Kefir Türk Gıda Kodeksi Fermente Süt Ürünleri Tebliği’nde "Fermentasyonda spesifik olarak Lactobacillus kefiri, Leuconostoc, Lactococcus ve Acetobacter cinslerinin değişik suşları ile laktozu fermente eden (Kluyveromyces marxianus) ve etmeyen mayalar1 (Saccharomyces unisporus, Saccharomyces cerevisiae ve Saccharomyces exiguus) içeren starter kültürler ya da kefir tanelerinin kullanıldığ fermente süt ürününü” şeklinde tanımlanmıştır (Anonim 2009). Kefir fermente asidik bir içecek olup özellikle de Kafkaslarda insan sağlığını yararlı etkileri nedeniyle oldukça fazla tüketilmektedir (Atalar, 2019). Kefir günümüzde sadece Kafkaslar'da değil Avrupa, Asya ve Rusya'da da tüketilmektedir (Delgado-Fernández vd., 2019). Laktik asit bakterileri, mayalar ve asetik asit bakterileri arasındaki simbiyotik ilişki kefirin kendine özgü tat ve aromasının oluşmasında etkilidir (Gul vd., 2018; Atalar, 2019; DelgadoFernández vd., 2019; Sulmiyati vd., 2019). Kefir doğal bir probiyotik olması ve besleyici içeriği nedeniyle insan beslenmesinde önemli bir yere sahiptir (Otles and Cagindi, 2003; Atalar, 2019; Sulmiyati vd., 2019). Kefirin tüketilmesinde sadece zengin besin içeriği değil, aynı zamanda laktoz intolaransı ve bağırsak hastalıklarına karşı koruyucu, (Gul vd., 2018) antimikrobiyal, antioksidatif, antikansorejenik, antihipertansif ve antiinflamatuar (Ürkek vd., 2011; DelgadoFernández vd., 2019) özellikleri etkili olmaktadır. Kefirin kalitesi kullanılan sütün çeşidinden (inek, koyun vb), kefir danesinin miktarından, laktik asit bakterilerinin ve mayaların çeşidinden ve inkübasyon zamanından önemli derecede etkilenmektedir (Sulmiyati vd., 2019). Bunlara ek olarak, üretimde kefir danesi veya starter kullanılması da kefirin kimyasal, mikrobiyolojik ve duyusal özelliklerini etkilemektedir (Dertli and Çon, 2017; Delgado-Fernández vd., 2019; Tomar vd., 2019). Özellikle endüstriyel kefir üretimde maya tadı daha az öne çıkmakta, bununla birlikte geleneksel olarak üretilen kefirlere göre endüstriyel üretilen kefirler daha viskoz bir yapiya sahip olmaktadırlar (Tomar vd., 2019).

Kefir danelerindeki mikrobiyal farklllı kefir danesinin kaynağından, daneyi üretme metotlarından, sanitasyon şartlarından ve koruma tekniklerinden kaynaklanmaktadır. Bu farklılıklar standart kefir üretiminde problemlere neden olmaktadır (Gul vd., 2018). Geleneksel üretimde kullanılan kefir danesi sahip olduğu farklı mikrobiyal içerikle kefirin kendine özgü tataromasının (Dertli and Çon, 2017) ve biyoaktif bileşiklerin oluşmasında önemli bir yere sahiptir. Liyofilize kefir kültürü endüstriyel üretimde standart bir ürün elde etmek için kullanılmaktadır. İnek sütü endüstriyel üretimde en çok tercih edilen süttür. Fakat diğer süt çeşitleri (koyun, keçi ve soya sütü gibi) de kullanılmaktadır. Ticari olarak üretilen kefirin lezzet, aroma ve ağızda bıraktığı his özellikleri bakımından kabul edilebilir düzeyde olması sağlanmalıdır (Gul vd., 2018). Ticari kefirlerin terapötik özellikleri geleneksel üretilmiş kefirlere göre daha düşük olabilir. Bunun sebebi ise ticari kefirlerde geleneksel kefirlerde olan bazı bakteri ve mayaların bulunmamasıdır (Tomar vd., 2019).

Bu çalışmada, endüstriyel üretilen ticari kefirlerin bazı fizikokimyasal, mikrobiyolojik, reolojik ve duyusal özelliklerinin belirlenmesi amaçlanmıştr. Ayrıca ticari kefirler arasındaki bazı özellikler bakımından farkl11ıklar da ortaya konulmuştur.

\section{MATERYAL VE YÖNTEM}

\section{Materyal}

Bu çalışmada ticari olarak piyasada satılan 6 farklı firmaya ait kefir örnekleri çeşitli marketlerden alınarak soğuk zincir altında laboratuvara ulaştırlmıştır. Tüm kefir örnekleri inek sütünden üretilmiş olup, meyve gibi katkılar içermeyen sade 
kefirlerden toplanmıştır. Kefirler rastgele K1, K2, K3, K4, K5 ve K6 şeklinde kodlanmışlardır.

\section{Yöntem}

\section{Fizikokimyasal Analizler}

Kefir örneklerinin kurumadde oran1 \% olarak gravimetrik yöntemle, asitlik değerleri titrasyon yöntemi ile \% laktik asit olarak belirlenmiştir (Demirci and Gündüz, 2004). pH değerleri birleşik elektrotlu pH metre (WTW 3110) ile tespit edilmiştir. Yağ değerlerinin belirlenmesinde Gerber metodu kullanılmıştır (Metin, 2009).

Kefir örneklerinin su tutma kapasiteleri (STK), Bensmira and Jiang (2012) tarafindan verilen metot modifiye edilerek tespit edilmiştir. Bunun için 10 gr kefir örnekleri falkon tüplerine tartılmıştır. Örnek koyulan tüpler 2750g'de (Nüve NF 200, Ankara) $4{ }^{\circ} \mathrm{C}$ 'de 30 dak satrifüjlenmiştir (Bensmira and Jiang, 2012). Sonuçlar aşağıdaki formüle göre hesaplanmıştur.

$S T K=\left(1-\frac{W_{1}}{W_{2}}\right) \times 100$

W1 = Santrifüjlemeden sonra kefirden ayrilan serumun ağırlığ

W2= Kefirden tartılan örnek miktarı.

\section{Viskozite ve Reolojik Analizler}

Kefir örneklerinin viskozite ölçümleri için Brookfield Viscometer Model DV-II cihaz1 kullanılmıştır. Ölçümler için 4 nolu başlık kullanılmıs, 30 sn rotasyon yapildıktan sonra değerler cP olarak verilmiştir. Reolojik değerleri Steffe (1967) tarafindan verilen "Power Law Modeli" kullanılarak belirlenmiştir. Bu modele göre değerler belirlenirken aşağıdaki formülden faydalanılmıstır. Formülde ifade edilen $\eta$ ile görünür viskozite (Pa.s), $K$ ile kıvam indeksi, $\gamma$ ile kayma hızı (rpm) ve $n$ ile akış davranış indeksi ifade edilmiştir.

$\eta=K \gamma^{(\mathbf{n}-1)}$

\section{Mikrobiyolojik Analizler}

Kefir örnekleri $(10 \mathrm{~mL}) 90 \mathrm{~mL} \% 0.85$ 'lik steril $\mathrm{NaCl}$ çözeltisinde seyreltilmiştir. Stomacher cihazinda (Interscience-Bagmixer 400 P, St Nom, Fransa) homojenize edilen kefir örneklerinden seri dilüsyonlar oluşturulmuştur. Laktobasil sayılar1 anaerobik şartlarda $30{ }^{\circ} \mathrm{C}$ 'de de 3 gün inkübe edilen MRS agarda oluşan koloniler sayılarak belirlenmiştir. Kefir örneklerinin laktokok sayıları M17 agar kullanılarak anaerobik şartlarda $30{ }^{\circ} \mathrm{C}$ 'de de 3 gün inkübüsyon sonrasında oluşan kolinler sayılarak belirlenmiştir. Koliform bakteri saylları Violet Red Bile Agar (VRBA) ile belirlenmiştir. Besiyerleri $37^{\circ} \mathrm{C}$ 'de 2 gün inkübasyon sonrasında oluşan koloniler sayılarak tespit edilmiştir. Maya küf sayısı \%10'luk steril tartarik asitten $14 \mathrm{mg} / \mathrm{L}$ ilave edilen Patato Dekstroz Agar (PDA)'da $25{ }^{\circ} \mathrm{C}$ 'de 5 gün inkübasyon sonucunda oluşan koloniler sayllarak belirlenmiştir (Irigoyen vd., 2005). Analiz sonuçları $\log \mathrm{kob} / \mathrm{mL}$ olarak verilmiştir.

\section{Duyusal Analizler}

Kefir örneklerinin belirlenmesinde eğitilmemiş panelistlerden oluşan 30 kişilik bir grup kullanılmıştır. Panelistler 20-40 yaş aralı̆̆ında 17 kadın 13 erkekten oluşmuştur. Panelistler örnekleri 1 ile 9 puan arasında değerlendirmiş ve 1: Asla beğenmedim, 2: Beğenmedim, 3: Orta düzeyde beğenmedim, 4: Hafif beğenmedim, 5: Ne beğendim ne beğenmedim, 6: Orta düzeyde beğendim, 7: Az beğendim, 8: Beğendim, 9: Çok beğendim olarak kabul edilmiştir (Meilgaard vd., 1999). Örnekler kıvam, asitlik, tat, koku, ağızda bıraktığ1 his ve genel kabul edilebilirlik gibi özellikler bakımdan değerlendirilmiştir.

\section{BULGULAR VE TARTIŞMA}

Kefir Örneklerinin Fizikokimyasal Özellikleri Kefir örneklerinin bazı fizikokimyasal ve reolojik özelliklerine ait değerler Çizelge 1'de verilmiştir. Kefir örneklerinde en yüksek kurumadde değeri K6 kodlu örnekte \%10.68 olarak en düşük ise K5 kodlu örnekte \%8.71 olarak belirlenmiştir. Ortalama kurumaddesi ise $\% 9.67$ olup K1, K2 ve K5 nolu örneklerin kurumadde değerlerinin ortalamanın altında olduğu tespit edilmiştir. Çetinkaya and Mus (2012), Bursa'da satılan kefirlerin en düşük, en yüksek ve ortalama kurumadde değerlerini sirasiyla $\% 8, \% 16.5$ ve \%11.3 olarak bulmuşlardır. Hecer vd. (2019) farklı sicaklık derecelerinde fermente ettiği kefir örneklerinin kurumadde değerlerini \%11.00 ile \%11.60 arasinda olduğunu belirlemişlerdir. Uslu (2010) tarafindan Ankara'da marketlerde satılan sade kefirlerin kurumadde değerlerini \%11.29- 
14.01 arasında değiştiğini tespit etmiştir. Çetinkaya and Mus (2012), Hecer vd. (2019) ve Irigoyen vd. (2005) tarafindan bulunan kurumadde değerlerinin bizim bulduğumuz değerlerden daha yüksek olduğu tespit edilmiştir.

Kefir örneklerinin $\mathrm{pH}$ değerleri 4.26 ile 4.37 arasında değişen değerler aldığ1 belirlenmiştir (Çizelge 1). Kefir örneklerinde en düşük asitlik değeri (\%0.67) K5 kodlu örnekte en yüksek $(\% 0.88)$ ise K1 ve K3 kodlu örneklerde tespit edilmiştir (Çizelge 1). Çetinkaya and Mus (2012), Bursa'da marketlerden topladiklan kefirlerin $\mathrm{pH}$ değerlerini 3.9 ile 4.7 arasında değiştiğini ortalamasının ise 4.30 olduğunu, asitlik değerlerinin ise $\% 0.7$ ile 1.4 arasında ve ortalama $\% 0.8$ olduğunu belirlemişlerdir. Hecer vd. (2019) farklı fermantasyon sicaklıkları uygulayarak ürettiği kefirlerin $\mathrm{pH}$ değerlerinin 3.90 ile 5.65 arasında bulmuşlardır. Goncu vd. (2017) tarafından yapılan çalışmada bir kısmına elma ve limon lifi ilave ederek, bir kısmına da hiçbir şey ilave etmeden ürettikleri kefirleri 20 gün boyunca depolamışlardır. Yapılan çalışma sonucunda kontrol örneğinin $\mathrm{pH}$ değerlerinin depolama süresince 4.48 ile 4.65 arasında değiştiğini tespit etmişlerdir. Bu çalışmada bulunan ortalama değer, Çetinkaya and Mus (2012) tarafindan bulunan ortalama değerden biraz yükssek, Hecer vd. (2019) ve Goncu vd. (2017) tarafindan bulunan değerlerin üst değerlerinden düşük olduğu belirlenmiştir. Türk Gıda Kodeksi Fermente Süt Ürünleri Tebliğine (Anonim, 2009) göre kefir en az \%0.60 asitlik değerine sahip olmalıdır. Buna göre tüm kefir örneklerinin asitlik değerlerinin tebliğ ile uyumlu olduğu ortaya konulmuştur. Fermente ürünlerde $\mathrm{pH}$ ve asitlik değerleri üzerinde fermantasyon sürecinin etkili olduğu ifade edilmektedir (Nielsen vd., 2014). Bu çalışmada örnekler arasında farklilıklar üzerinde ürünler arasındaki mikroorganizma sayılarındaki farklı1ıkların neden olduğu düşünülmektedir.

Çizelge 1. Kefir örneklerinin bazı fizikokimysal ve reolojik özellikleri Table 1. Some physicochemical and rhelogical properties

\begin{tabular}{|c|c|c|c|c|c|c|c|c|}
\hline $\begin{array}{l}\text { Kefir } \\
\text { Örnekleri } \\
\text { Kefir samples }\end{array}$ & $\begin{array}{c}\text { Kurumadde } \\
(\%) \text { Dry } \\
\text { matter }(\%)\end{array}$ & $\mathrm{pH}$ & $\begin{array}{c}\text { Asitlik } \\
\text { (\% laktik } \\
\text { asit) Acidity } \\
\text { (\% lactic } \\
\text { acid) }\end{array}$ & $\begin{array}{c}\text { Yağ } \\
(\%) \\
\text { Fat }(\%)\end{array}$ & $\begin{array}{c}\text { Su tutma } \\
\text { kapasitesi } \\
(\%) \\
\text { Water } \\
\text { bolding } \\
\text { capacity }(\%) \\
\end{array}$ & $\begin{array}{c}K \\
(\mathrm{~Pa} \mathrm{sn})\end{array}$ & $n$ & $\mathrm{R}^{2}$ \\
\hline K1 & 9.38 & 4.26 & 0.88 & 1.30 & 30.25 & 2.89 & 0.37 & 0.9994 \\
\hline K2 & 8.96 & 4.33 & 0.83 & 2.10 & 31.25 & 1.30 & 0.44 & 0.9995 \\
\hline K3 & 10.13 & 4.36 & 0.88 & 0.55 & 38.00 & 4.82 & 0.32 & 0.9934 \\
\hline K4 & 10.16 & 4.33 & 0.80 & 0.95 & 33.10 & 8.16 & 0.26 & 0.9965 \\
\hline K5 & 8.71 & 4.37 & 0.67 & 0.90 & 38.75 & 6.06 & 0.33 & 0.9998 \\
\hline K6 & 10.68 & 4.33 & 0.84 & 2.90 & 29.45 & 2.10 & 0.45 & 0.9999 \\
\hline $\begin{array}{l}\text { En düşük } \\
\text { The lowest }\end{array}$ & 8.71 & 4.26 & 0.67 & 0.55 & 29.45 & 1.24 & 0.27 & \\
\hline $\begin{array}{l}\text { En Yüksek } \\
\text { The highest }\end{array}$ & 10.68 & 4.37 & 0.88 & 2.90 & 38.75 & 8.19 & 0.44 & \\
\hline $\begin{array}{l}\text { Ortalama } \\
\text { Average }\end{array}$ & 9.67 & 4.33 & 0.82 & 1.45 & 33.47 & 4.25 & 0.36 & \\
\hline $\begin{array}{l}\text { Standart } \\
\text { sapma } \\
\text { Standard } \\
\text { deviation }\end{array}$ & 0.77 & 0.04 & 0.08 & 0.88 & 4.00 & 2.62 & 0.07 & \\
\hline
\end{tabular}

cP: centi-poise, $K$ : Kıvam katsayıs1, $n$ :Akış davranış indeksi, cP: centi-poise, K: consistency coefficient, $n: F$ low behavior index 
Kefir örneklerinin yağ değerleri Çizelge 1'de gösterilmiştir. En düşük yağ değeri \%0.55 ile K3 örneğinde en yüksek ise \%2.90 ile K6 kodlu örnekte belirlenmiştir. Tomar vd. (2019), inek ve manda sütünden kefir üretmişler, inek sütünden üretilen kefirin yağ oranını $\% 3.04$ ve manda sütünden üretilen kefirin yağ oranını ise $\% 3.05$ olarak belirlemişlerdir. Çetinkaya and Mus (2012), ticari kefirlerin en düşük, en yüksek ve ortalama yağ oranlarını sırasiyla $\% 0.3, \% 4.5$ ve $\% 2.3$ olarak bulmuşlardır. Uslu (2010) Ankara'da marketlerde satılan sade kefirlerin yağ değerlerini en düşük $\% 1.95$, en yüksek $\% 3.12$ ve ortalama $\% 2.67$ olarak tespit etmiştir.

Su tutma kapasitesi kefir örneklerinde \%29.45 ile $\% 38.75$ arasında değiştiği, ortalama değerinin ise \%33.47 olduğu tespit edilmiştir (Çizelge 1). K5 kodlu örnek en yüksek su tutma kapasitesine sahip iken en düşük K6 kodlu örneğin sahip olduğu belirlenmiştir. Atalar (2019), farklı oranlarda findık sütü karıştırılmıss sütten elde edilen kefirlerin su tutma kapasitelerinin \%18.55-38.71 arasında değiştiğini tespit etmişlerdir. Goncu vd. (2017) tarafindan yapilan çalışmada elma ve limon lifi ilave edilmeden üretilen kefirlerin su tutmam kapasitelerinin depolama süresince \%35.73-38.76 arasında olduğunu belirlemişlerdir. Gul vd.
(2018), manda sütünden kefir danesi ve starter kültür ile ürettikleri kefir örneklerinin su tutma kapasitelerini \%42.61 ile \%77.35 arasinda bulmuşlardır. Bu çalışmada bulunan ortalama su tutma kapasitesi değerinin Goncu vd. (2017) ve Gul vd. (2018) tarafindan bulunan değerlerden düşük, Atalar (2019) tarafindan bulunan değerlerin bir kısmından yüksek bir kısmından düşük olduğu belirlenmiştir.

Kefir örneklerinin 50 rpm'deki ortalama viskozite değeri 318.46 cP iken 100 rpm'deki ortalama değer $196.36 \mathrm{cP}$ olarak bulunmuştur. En yüksek viskozite değerine 50 rpm'de K4 kodlu örnek sahip olduğu tespit edilmiştir (Şekil 1). Örnekler arasında $100 \mathrm{rpm}$ de en yüksek viskozite değeri K5 kodlu örneğin sahip olduğu belirlenmiştir. Irigoyen vd. (2005), farklı oranlarda kefir danesi ilave ederek ürettikleri kefirleri 28 gün depolamışlar ve depolama süresince örneklerin 100 rpm'deki viskozite değerlerinin \%1 kefir danesi ilave edilen örneklerde 179 ile $425 \mathrm{cP}$ arasinda, \%5 ilave edilenlerde ise 296 ile $501 \mathrm{cP}$ değiştĭgini tespit etmişlerdir. Araştırmacılar tarafindan bulunan değerler bu çalışmada bulunan 100 rpm'deki viskozite değerlerinden daha yüksektir.

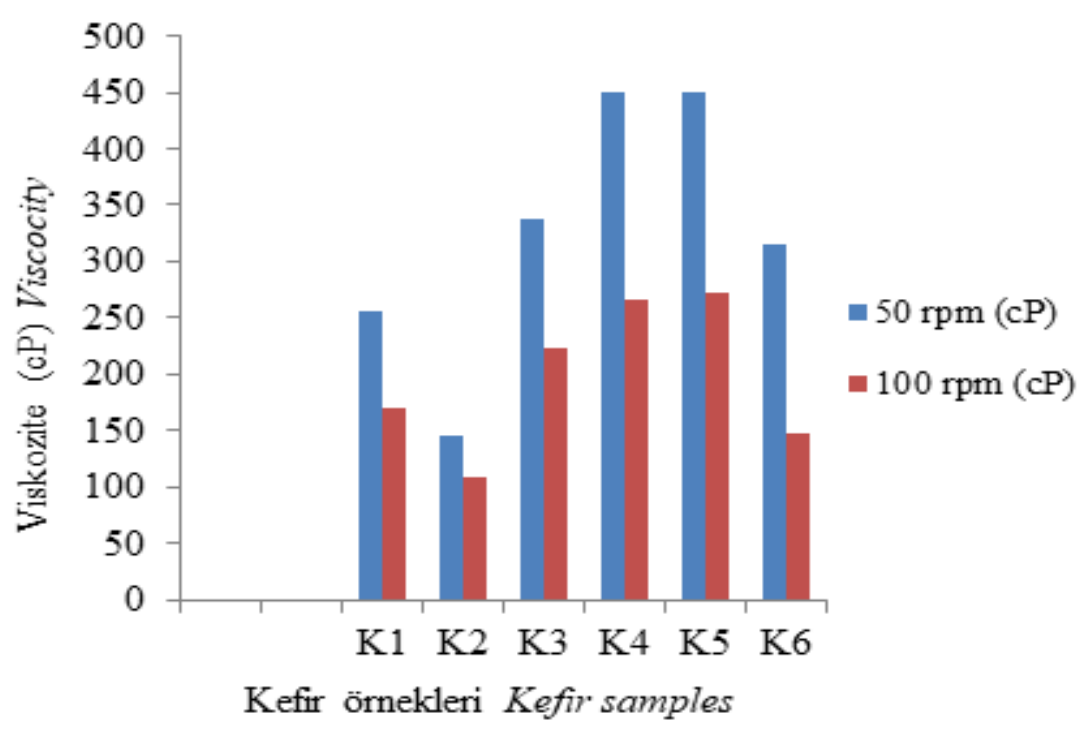

Şekil 1. Kefir örneklerinin 50 ve 100 rpm'deki viskozite değerleri Figure 1. Viscocity values at 50 and $100 \mathrm{rpm}$ of kefir samples 
Power law modelinde kıvam katsayısı $(K)$ ve akış davranış indeksi $(n)$ olmak üzere iki parametre bulunmakta olup akışkan gıdaları karakterize etmekte kullanılmaktadırlar. $K$ değeri gidalarda kıvam indeksine olarak başvurulurken, $n$ değeri ise Newtonyen akışa yakınlığını göstermektedir (Rao, 2014). Kefir örneklerinde en düşük $K$ değerinin K2 kodlu örnekte, en yüksek K4 kodlu örnekte bulunmuştur (Çizelge 1). Akışkanlanın $n=1$ ise Newtonyen, $n>1$ ise dilitant, $0<n<1$ ise psödoplastik davranış göstermektedirler (Steffe, 1967; Rao, 2014). Tüm kefir örneklerinin $n$ değerleri 0.26-0.45 arasında belirlenmiştir. Buna göre tüm kefir örnekleri psödoplastik akış gösterdiği ortaya konulmuştur. Gul vd. (2018), tarafindan yapılan çalşmada manda ve inek sütünden üretilen kefirlerin $K$ değerlerinin 2.947 ile 9.014 arasında, $n$ değerlerinin ise 0.332-0.412 arasında değiştiğini ortaya koymuşlardır.

Kefir Örneklerinin Mikrobiyolojik Özellikleri Kefir örneklerine ait mikrobiyoljik özellikler Çizelge 2'de verilmiştir. Kefir örneklerinin laktobasil sayıları 8.15 ile $9.09 \log \mathrm{kob} / \mathrm{mL}$ arasında değisstiği ve ortalama değerin ise $8.47 \mathrm{log}$ $\mathrm{kob} / \mathrm{mL}$ olduğu belirlenmiştir. En yüksek laktobasil sayıs1 $\mathrm{K} 2$, en düşük ise $\mathrm{K} 1$ kodlu örnekte tespit edilmiştir. Çetinkaya and Mus (2012), Bursa'da satilan ticari kefirlerin laktobasil sayılarının $1 \log \mathrm{kob} / \mathrm{mL}$ ile $8.77 \log \mathrm{kob} / \mathrm{mL}$ arasında değiştiğini, ortalama değerini $7.56 \mathrm{log}$ kob/mL olarak bulmuşlardır. Öner vd. (2010), inek, koyun ve keçi sütü ile kefir danesi ve starter kültür kullanilarak üretilen kefirlerin laktobasil sayilarının $7.406 \log \mathrm{kob} / \mathrm{mL}$ ile $8.822 \log$ $\mathrm{kob} / \mathrm{mL}$ arasında olduğunu tespit etmişlerdir. Hecer vd. (2019) tarafindan yapılan çalışmada, farklı fermantasyon sicaklığ1 uygulanan kefirlerin laktobasil sayılarının 4.45-7.54 log $\mathrm{kob} / \mathrm{mL}$ aralığında olduğunu belirlemişlerdir. Bu çalışmada bulunan değerler Çetinkaya and Mus (2012) ve Hecer vd. (2019) tarafindan bulunan değerlerden yüksek, Öner vd. (2010) tarafindan bulunan değerler ile benzerlik gösterdiği belirlenmiştir.

Çizelge 2. Kefir örneklerinin mikrobiyolojik özellikleri (log kob/mL) Table 2. Microbiological properties of kefir samples (log CFU/mL)

\begin{tabular}{|c|c|c|c|c|}
\hline $\begin{array}{l}\text { Kefir örnekleri } \\
\text { Kefir samples }\end{array}$ & $\begin{array}{c}\text { Laktobasil sayis1 } \\
\text { Lactobacil count }\end{array}$ & $\begin{array}{c}\text { Laktokok sayis1 } \\
\text { Lactococ count }\end{array}$ & $\begin{array}{l}\text { Maya-küf sayıs } \\
\text { Mould-yeast count }\end{array}$ & $\begin{array}{c}\text { Koliform bakteri } \\
\text { sayis1 Coliform } \\
\text { bacteria count }\end{array}$ \\
\hline K1 & 8.15 & 8.70 & 5.04 & ND \\
\hline K2 & 9.09 & 8.84 & 5.37 & ND \\
\hline K3 & 8.39 & 8.77 & 4.97 & ND \\
\hline K4 & 8.30 & 8.39 & 5.08 & ND \\
\hline K5 & 8.39 & 8.65 & 4.38 & ND \\
\hline K6 & 8.48 & 9.34 & 4.62 & ND \\
\hline En düşük The lowest & 8.15 & 8.39 & 4.38 & \\
\hline $\begin{array}{l}\text { En Yüksek } \\
\text { The highest }\end{array}$ & 9.09 & 9.34 & 5.37 & \\
\hline $\begin{array}{l}\text { Ortalama } \\
\text { Average }\end{array}$ & 8.47 & 8.78 & 4.91 & \\
\hline $\begin{array}{l}\text { Standart sapma } \\
\text { Standard } \\
\text { deviation }\end{array}$ & 0.32 & 0.31 & 0.35 & \\
\hline
\end{tabular}

ND: Tespit edilemedi, ND: Not detected 
Örneklerin en düşük, en yüksek ve ortalama laktokok sayıları sirasıyla $8.39 \log \mathrm{kob} / \mathrm{mL}, 9.34$ $\log \mathrm{kob} / \mathrm{mL}$ ve $8.78 \log \mathrm{kob} / \mathrm{mL}$ olarak tespit edilmiştir (Çizelge 2). En düşük K4 kodlu örnekte en yüksek ise K6 koldu örnekte belirlenmiştir. Harmankaya vd. (2019) sade, muz, çilek ve şeftali içerikli kefirler üretmişler, sade kefirlerin laktokok sayılarının 14 günlük depolama süresince 6.681 $\log \mathrm{kob} / \mathrm{mL}$ ile $9.079 \log \mathrm{kob} / \mathrm{mL}$ arasinda değiştiğini belirlemişlerdir. Çetinkaya and Mus (2012), kefir örneklerinin laktokok sayılarını en düşük $5 \log \mathrm{kob} / \mathrm{mL}$, en yüksek $8.80 \log \mathrm{kob} / \mathrm{mL}$ ve ortalama $8.26 \log \mathrm{kob} / \mathrm{mL}$ olarak bulmuşlardır. Irigoyen vd. (2005), yaptığ1 çalışmada kefir örneklerinin ortalama laktokok sayısını 8 log $\mathrm{kob} / \mathrm{mL}$ olarak tespit etmişlerdir. Bu çalışmada belirlenen ortalama laktokok sayılarının Çetinkaya and Mus (2012) ve Irigoyen vd. (2005) tarafindan bildirilen değerlerden daha yüksek değereler sahip olduğu ortaya konulmuştur. Tebliğe göre (Anonim, 2009), kefir en az $7 \log \mathrm{kob} / \mathrm{mL}$ spesifik mikroorganizma içermelidir. Tüm kefir örnekleri hem laktobasil hem de laktokok saylar1 bakımından tebliğe uygun olduğu, tebliğde verilen değerlerden daha yüksek mikroorganizma sayllarına sahip olduğu tespit edilmiştir.

Kefir örneklerinde maya-küf sayısı olarak sadece maya tespit edilmiştir. Kefir örneklerinin ortalama maya-küf sayıs1 $4.91 \quad \log \mathrm{kob} / \mathrm{mL}$ olarak belirlenmiştir (Çizelge 2). Öner vd. (2009) tarafından yapılan çalışmada, inek sütünden kefir danesi ile ürettiği kefirlerin maya-küf sayılarının 15 günlük depolama süresince 4.698 ile $5.342 \mathrm{log}$ $\mathrm{kob} / \mathrm{mL}$ arasında iken, starter kültür ile üretilenlerde 6.372 ile $6.658 \mathrm{log} \mathrm{kob} / \mathrm{mL}$ arasında değiştiğini tespit etmişlerdir. Çetinkaya and Mus (2012) yaptıkları çalışmada, ortalama maya-küf sayısını $6.89 \log \mathrm{kob} / \mathrm{mL}$, Irigoyen vd. (2005) ise ortalama sayıy $5 \log \mathrm{kob} / \mathrm{mL}$ olarak bulmuşlardır. Uslu (2010) Anakara piyasasında satılan kefirlerin en yüksek, en düşük ve ortalama maya küf sayılarını sirasiyla $6.43,6.90$ ve $6.70 \log \mathrm{kob} / \mathrm{mL}$ belirlemiştir. $\mathrm{Bu}$ çalışmalarda araştırmacılar tarafından bulunan değerlerin genel olarak bizim çalışmamızda bulduğumuz değerlerden daha yüksek olduğu tespit edilmiştir. Fermente Süt Ürünleri Tebliği'nde kefirlerin maya-küf sayılarının en az 4 log $\mathrm{kob} / \mathrm{mL}$ olması istenilmektedir. Tüm kefir örneklerinin maya-küf sayıları tebliğe uygun olduğu ortaya konulmuştur.

Kefir örneklerinde koliform bakteri tespit edilmemiş olup, tüm örneklerin tebliğe uygun olduğu belirlenmiştir. Benzer şekilde Öner vd. (2009) yaptıkları çalışmada, kefir örneklerinde koliform bakteri tespit etmemişlerdir. Kalkan (2019) yaptı̆̆1 çalışmada, mikroenkapsüle Saccharomyces cerevisiae var. boulardii ilave ederek ürettiği kefir örneklerinde koliform bakteri tespit edememişlerdir.

\section{Kefir Örneklerinin Duyusal Özellikleri}

Kefir örnekleri 30 farklı tüketici tarafindan değerlendirilmiş olup, panelistler tarafindan verilen puanlar Çizelge 3'te gösterilmiştir. Tüm duyusal özellikler bakımından en çok beğenilen kefir örneğinin K4 kodlu örneğin olduğu belirlenmiştir. Kıvam, asitlik, tat ve genel kabul edilebilirlik özellikleri bakımında en az beğenilen örneğin K3, koku ve ağızda biraktığ1 his bakımından ise en düşük puanları K6 kodlu örneğin aldığ1 tespit edilmiştir. Genel olarak tüm duyusal özellikler 9 puan değerlendirilmesine karşın kefir örneklerinin aldığı puanların ortalama değerlerin altında olduğu ortaya konulmuştur. Özellikle genel kabul edilebilirlik açısından kefir örneklerinin genel olarak 5 puanın altında alması halen genel olarak kefirlerin halk tarafindan damak tadı olarak tam benimsenemediğini göstermektedir. Yapılan bazı anket çalışmalarında araştırmaya katılanların büyük çoğunluğunun (\%84.7) kefir tüketmediğini ve büyük bir kısmının $(\% 52)$ ise kefirin sağllğa faydaları hakkında herhangi bir bilgiye sahip olmadığı belirlenmiştir (Tarakçi vd., 2015).

\section{SONUÇ}

Bu çalışmada, ulusal olarak satılan kefirlerin bazı fizkokimyasal, reolojik, mikrobiyolojik ve duyusal özelliklerinin incelenerek, örneklerin kalite özellikleri belirlenmiştir. Tüm kefir örneklerinin asitlik değerlerinin, laktobasil, laktokok ve mayaküf sayılarının Fermente Süt Ürünleri Tebliği’nde belirtilen değerlere uygun olduğu belirlenmiştir. Hiçbir kefir örneğinde koliform bakteri belirlenmemiştir. Kefir örnekleri arasında kurumadde, yağ, viskozite (50 ve $100 \mathrm{rpm}$ ), K 
değerleri bakımından farklılıklar tespit edilmiştir. Duyusal özellikler bakımından hemen hemen tüm kefir örnekleri oldukça düşük puanlar almışlardır. Sonuç olarak kefirin kimyasal ve mikrobiyolojik özellikler bakımından tebliğe uygun olmasına karşin, tebliğde kurumadde ve yağ değerlerinin bir alt sinır1 olmas1 daha standart bir üretim sağlayabilir. Buna ek olarak kefirin faydaları hakkında bilinçlendirmeye ve kefir tüketimini arttırılmasına yönelik çalışmalar yapılmasının faydalı olacağı kanaatindeyiz.

Çizelge 3. Kefir örneklerinin duyusal özellikleri

Table 3. Sensorial properties of kefir samples

\begin{tabular}{lcccccc}
\hline $\begin{array}{l}\text { Kefir örnekleri } \\
\text { Kefir samples }\end{array}$ & $\begin{array}{c}\text { Kivam } \\
\text { Consitency }\end{array}$ & $\begin{array}{c}\text { Asitlik } \\
\text { Acidity }\end{array}$ & Tat & Koku & $\begin{array}{c}\text { Ağıda } \\
\text { B1raktı̆1 His }\end{array}$ & $\begin{array}{c}\text { Genel Kabul } \\
\text { Edilebilirlik }\end{array}$ \\
\hline K1 & 5.29 & 4.71 & 4.00 & 4.07 & 3.75 & 4.30 \\
K2 & 4.64 & 4.39 & 3.57 & 3.61 & 3.46 & 4.26 \\
K3 & 4.11 & 3.36 & 3.07 & 3.68 & 3.36 & 3.89 \\
K4 & 6.04 & 5.32 & 5.39 & 5.68 & 5.36 & 5.70 \\
K5 & 5.04 & 4.61 & 4.93 & 5.00 & 4.68 & 4.81 \\
K6 & 4.57 & 3.82 & 3.43 & 3.18 & 3.25 & 3.96 \\
\hline $\begin{array}{l}\text { En düşük The lowest } \\
\text { En Yüksek }\end{array}$ & 4.11 & 3.36 & 3.07 & 3.18 & 3.25 & 3.89 \\
$\begin{array}{l}\text { The bighest } \\
\text { Ortalama }\end{array}$ & 6.04 & 5.32 & 5.39 & 5.68 & 5.36 & 5.70 \\
$\begin{array}{l}\text { Average } \\
\text { Standart sapma }\end{array}$ & 4.95 & 4.37 & 4.07 & 4.20 & 3.98 & 4.49 \\
$\begin{array}{l}\text { Standard } \\
\text { deviation }\end{array}$ & 0.67 & 0.69 & 0.91 & 0.95 & 0.85 & 0.68 \\
\hline
\end{tabular}

\section{KAYNAKLAR}

Anonim. (2009). Fermente Süt Ürünleri Tebliğ (Tebliğ No: 2009/25).

Atalar, I. (2019). Functional kefir production from high pressure homogenized hazelnut milk. Lwt- Food Sci Technol, 107: 256-263. https://doi.org/10.1016/j.lwt.2019.03.013

Bensmira, M., Jiang, B. (2012). Effect of some operating variables on the microstructure and physical properties of a novel Kefir formulation. $J$ Food Eng, 108(4): 579-584. https://doi.org/10.1016/j.jfoodeng.2011.07.025

Çetinkaya, F., Mus, T. E. (2012). Determination of microbiological and chemical characteristics of kefir consumed in Bursa. Ankara Üniversitesi Veteriner Fakültesi Dergisi, 59: 217-221. https://doi.org/10.1501/vetfak_0000002528

Delgado-Fernández, P., Corzo, N., Lizasoain, S., Olano, A., Moreno, F. J. (2019). Fermentative properties of starter culture during manufacture of kefir with new prebiotics derived from lactulose. Int Dairy J, 93: 22-29. https://doi.org/10.1016/j.idairyj.2019.01.014

Demirci, M., Gündüz, H. H. (2004). Süt Teknoloğunun El Kitabı. İstanbul: Turkey: Hasad Yayınlar1..

Dertli, E., Çon, A. H. (2017). Microbial diversity of traditional kefir grains and their role on kefir aroma. LWT - Food Sci Technol, 85: 151-157. https://doi.org/10.1016/j.lwt.2017.07.017

Farnworth, E. R. (2005). Kefir - a complex probiotic. Food Science and Technology Bulletin: Functional Foods, 2(1), 1-17. https://doi.org/ 10.1616/1476-2137.13938

Goncu, B., Celikel, A., Guler-Akin, MB., Akin, MS. (2017). Some properties of kefir enriched with apple and lemon fiber doi: Mjekarstvo 
67:208-216. doi: $10.15567 /$ mljekarstvo. 2017.0305

Gul, O., Atalar, I., Mortas, M., Dervisoglu, M. (2018). Rheological, textural, colour and sensorial properties of kefir produced with buffalo milk using kefir grains and starter culture: A comparison with cows' milk kefir. Int J Dairy Technol, 71(March): 73-80. https://doi.org/ 10.1111/1471-0307.12503

Harmankaya, S., Gülbaz, G., Kamber, U. (2019). Microbiological, chemical and sensory characteristics of kefir prepared with various fruit additives. Van Veterinary Journal, 30(1): 13-18.

Hecer, C., Ulusoy, B., Kaynarca, D. (2019). Effect of different fermentation conditions on composition of kefir microbiota. Int Food Res J 26:401-409

Irigoyen, A., Arana, I., Castiella, M., Torre, P., Ibáñez, F. C. (2005). Microbiological, physicochemical, and sensory characteristics of kefir during storage. Food Chem, 90(4): 613-620. https://doi.org/10.1016/j.foodchem.2004.04.02 1

Kalkan, S. (2019). Mikroenkapsüle Saccharomyces cerevisiae var. boulardii kullanılarak üretilen kefirin baz1 kalite özelliklerinin belirlenmesi. Iğdır Üniversitesi Fen Bilimleri Enstitïsü Dergisi, 9(1): 572580. https://doi.org/10.21597/jist.435476

Meilgaard, M. C., Carr, B. T., Civille, G. V. (1999). Sensory Evaluation Techniques. In Boca Raton, FL:CRC Pres, Inc. (3rd ed.). https://doi.org/10.1017/S1431927611002686

Metin, M. (2009). Süt ve Mamulleri Analiz. Yöntemleri. İzmir, Turkey: EÜ, Ege Meslek Yüksekokulu Yay. No: 24.

Nielsen, B., Gürakan, G. C., Ünlü, G. (2014). Kefir: A multifaceted fermented dairy product. Probiotics and Antimicrobial Proteins, 6(3-4): 123135. https://doi.org/10.1007/s12602-014-91680

Öner, Z., Karahan, A. G., Çakmakçı, M. L. (2010). Effects of different milk types and starter cultures on kefir. Grda, 35(3): 177-182.
Otles, S., Cagindi, O. (2003). Kefir: A probiotic dairy-composition, nutritional and therapeutic aspects. Pakistan Journal of Nutrition, 2(2): 54-59.

Rao, M. A. (1999). Rheology of Fluid and Semisolid Foods: Principles and Applications (3th ed.), Aspen Publishers, Inc., Gaithersburg, Maryland.

Steffe, J. F. (1967). Rheological Methods in Food Process Engineering (2nd ed.). https://doi.org/10.1016/B978-1-4832-32454.50016-9

Sulmiyati, Said, N. S., Fahrodi, D. U., Malaka, R., Maruddin, F. (2019). The physicochemical, microbiology, and sensory characteristics of kefir goat milk with different levels of kefir grain. Tropical Animal Science Journal, 42(2): 152-158. https://doi.org/10.5398/tasj.2019.42.2.152

Tarakçi, Z., Karaağaç, M., Çelik, Ö. F. (2015). Araşturma Ordu il merkezindeki tüketicilerin fermente süt ürünleri tüketim alışkanlıkları. Akademik. Ziraat Dergisi, 4(2): 71-80.

Tomar, O., Akarca, G., Çağlar, A., Beykaya, M., Gök, V. (2019). The effects of kefir grain and starter culture on kefir produced from cow and buffalo milk during storage periods. Food $S_{c i}$ Technol (N Y), 2061: 3-9. https://doi.org/10.1590/ fst.39418

Uslu, G. (2010). Ankara piyasasinda sattlan kefirlerin mikrobiyolojik, fiziksel, kimyasal ve duyusal özellikleri üzerine bir araştırma. Ankara Üniversitesi Fen Bilimleri Enstitüsü Süt Teknolojisi Anabilim Dalı Yüksek Lisans Tezi, Ankara, Türkiye, $70 \mathrm{~s}$.

Ürkek, B., Erkaya, T., Şengül, M. (2011). Kefir: Bileşimi, üretimi, probiyotik ve terapötik Özellikleri. Akademik Gıda, 9(5): 60-66.

Yıldı-Akgül, F., Yetişemiyen, A., Şenel, E., Yildirım, Z. (2018). Microbiological, physicochemical, and sensory characteristics of kefir produced by secondary fermentation. Mljekarstvo, 68(3): 201-213. https://doi.org/ $10.15567 / \mathrm{mljekarstvo.2018.0305}$ 